\title{
Multimorbiditás, elörehaladott életkor a kardiológiai rehabilitációban. Speciális megfontolások
}

\author{
Andrássy Gábor \\ Budapesti Szt. Ferenc Kórház, Kardiológiai Rehabilitációs Osztály, Budapest
}

Levelezési cím: Dr. Andrássy Gábor PhD, Budapesti Szt. Ferenc Kórház, Kardiológiai Rehabilitációs Osztály 1021 Budapest, Széher u. 73. E-mail: e-mail: andrassy@szentferenckorhaz.hu

Az eljövendő évtizedekben az idősek részaránya a népességben növekedni fog, beleértve a 80 éven felüliek számának növekedését is. Az elmúlt évtizedekben az akut betegellátásban jelentős elörehaladás történt, amelynek eredményeképpen az idős betegek túlélési esélyei is javultak. Ennek következtében a kardiológiai rehabilitációban is fokozottan szembe kell néznünk az időskorral, a multimorbiditással, a csökkent képességekkel, és az esendőséggel. Ismert, hogy a kardiológiai rehabilitáció minden korosztályban hatékony és biztonságos, de tudatában kell lennünk annak, hogy az idősek és esendő betegek kockázata fokozott, több a komplikáció és gyors a dekondicionálódás.

Kulcsszavak: kardiológiai rehabilitáció, időskor, multimorbiditás

\section{Multimorbidity and advanced age in cardiac rehabilitation. Special considerations}

The share of older persons in the total population will increase significantly in the coming decades; the percentage of older adults over the age of 80 continues to expand. In the last decades, there have been remarkable advances in the acute medical care, resulting improved chance of survival including the aged cardiac patients. Consequently, ageing, multimorbidity, disability and frailty have come into sight also in cardiac rehabilitation that we must face. However, it was postulated, that cardiac rehabilitation is effective and safe in all ages, we have to be aware, that frail patients are at a higher risk for complications and accelerated physical deconditioning. Caregivers in cardiac rehabilitation should pay special attention to this circumstance.

Keywords: cardiac rehabilitation, advanced age, multimorbidity

\section{Demográfiai tények}

Az Eurostat 2017-es adatai szerint a tartósan alacsony születési szám és a meghosszabbodott élettartam miatt megváltozik az EU 28-ak korfája, az idősek száma emelkedni fog és ez a folyamat már több EU-tagállamban elkezdődött (1). A munkaképes és az aktív korban lévők részaránya csökken, a nyugalomba vonultak relatív aránya nő, ami fokozódó terhet jelent a társadalom számára. 2080-ra az EU 28-ak lakosságában a 65 éven felüliek aránya 19,2\%-ról 29,1\%-ra emelkedik majd. Kiemelendő, hogy az igen idősek részaránya gyorsabban nő, mint bármely másik korosztály, így az EU 28-ak népességében a 80 éven felüliek részaránya 2016 és 2080 között több mint kétszeresére, 5,4\%-ról 12,7\%-ra fog nőni.

\section{Hosszabb élettartam}

Az élettartam leginkább a fejlett országokban hosszabbodott meg. Dán és svéd egypetéjü ikrek adatai alapján az élettartamért csupán negyed-ötödrészben felelősek az örökölt gének, jóval nagyobb a környezeti tényezők 
szerepe (2, 3). Természetes és védett körülmények között élő állatokat összehasonlítva hasonló eredmények mutatkoztak $(4,5)$.

A demográfiakutatók szerint a hosszabb élet hátterében a javuló életkörülmények, a jobb oktatás és a fejlettebb egészségügyi ellátás játssza a fő szerepet (6). A fejlett országok sokat invesztálnak a költséges egészségügyi kutatásokba, egészségügyi rendszerük hatékony, biztosítják az innovatív kezeléseket még akkor is, ha azok költségesek. Ha az embereknek lehetőségük van a minőségi lakhatásra, ruházkodásra, hozzá jutnak egészséges élelemhez és élvezhető az életük, jobb esélyük van elérni az időskort. Az egészségügyi ellátás minősége nem szükségszerüen csökkenti az időskori mortalitást, de mindenképpen segíti a fogyatékosságok csökkentését. Az oktatás is fontos tényező. A művelt emberek, mivel többet tudnak az egészséges életmódról, általában hosszabb ideig élnek, akik pedig dohányoznak, testmozgást nem végeznek és erősen elhízottak, rövidebb élettartamra számíthatnak.

\section{A kardiológiai rehabilitáció}

Az Egészségügyi Világszervezet (WHO) 1964-es meghatározása szerint a kardiológiai rehabilitáció mindazon tevékenységek összessége, amelyek révén a kardiovaszkuláris eseményt elszenvedett betegek - saját tevőleges közremüködésükkel - a legjobb egészségi-, fizikai-, mentális- és szociális állapotba kerülhetnek, illetve visszanyerhetik korábbi társadalmi pozíciójukat és újból aktívan élhetnek. Az elmúlt két évtizedben, a kardiális eseményeket követő fizikai tréningre alapozott kardiológiai rehabilitációs programok fokozatosan komplex életmód-programokká alakultak. Ezek a komplex multifaktoriális programok a fő komponensek mellett (dohányzás, diéta, és rizikófaktorok), többek között egészségnevelést, viselkedésterápiát és gyógyszeres másodlagos megelőzést is tartalmaznak.

\section{A rehabilitációba kerülö betegpopuláció megváltozása}

Az elmúlt évtizedekben a szívbetegségek diagnosztikája és kezelése soha nem látott fejlődésen ment keresztül. Kitágultak a konzervatív terápiás lehetőségek is, de az intervenciós eljárások és eszközbeültetések sokszor azonnal, drámaian befolyásolják a betegség természetes lefolyását. Például, az akut koronária szindróma intervenciós kezelése mellett sok beteg az akut szakaszt szinte „meg sem éli”, mert a koronáriaelzáródás megszúnése pillanatokon belül panaszmentességhez vezethet. A prognózis optimalizálása végett e betegek számára is alapvető, hogy rehabilitációs programba kerüljenek, de mivel betegségtudatuk nem alakul ki, sokszor mereven elzárkóznak a rehabilitációtól.

1. TÁBLÁZAT. A kardiológiai rehabilitációba érkező betegek jellemzői

\section{Korábban}

Dekondícionált, súlyosan hospitalizált beteg

20-30 \% kórházi mortalitás: „természetes szelekció”

Relatíve homogén betegcsoport, inkább fiatalabb

„Infaust” eset otthon vagy

a belosztályon

Katartikus élményen átesett

Hangsúly a fizikai

edzésprogramon

2. TÁBLÁZAT. Felvételi diagnózisok a Budapesti Szt. Ferenc Kórház Kardiológiai Rehabilitációs osztályán

\section{Felvétel oka}

Egyéb szívbetegség

Szívinfaktus és $\mathrm{PCl}$

Szívbillentyü- és nagyérmütét után

Koszorúérmütét után

Egyéb

3. TÁBLÁZAT. Nem kardiológiai társbetegségek előfordulása a Budapesti Szt. Ferenc Kórház kardiológiai rehabilitációs osztályán

\section{Társbetegség}

Hipertónia

Anémia

Diabetes mellitus

Neuro-psych.

Nicotinismus (anamn.+jelenleg)

Obesitas

Mozgásszervi

Veseelégtelenség

PAD+sign. carotis sten.

Malign. anamn.

Pajzsmirigy-diszfunkció

COPD

Tromboembol. anamn.

\section{$\%$} 74 39

34

34

28

26
20

19

19

18

13

13

12

9

5
Másfelől, a hatékony akut ellátás esélyt jelenthet azon elesett, idős, multimorbid betegek számára, akiket korábban elveszítettünk. A rehabilitációba kerülő megváltozott betegpopuláció néhány jellemzőjét az 1. táblázat mutatja.

A kardiológiai rehabilitációs fekvőbeteg-ellátásba érkező betegek felvételi indikációit és társbetegségeit elemeztük a Budapesti Szt. Ferenc Kórházba 2017. 
március 1-től folytatólagosan érkező 100 betegen (férfi 64, nő 36), életkor=72 $\pm 12,3$ (38-104) év, 2. és 3. táblázat. Szembetűnő a betegek előrehaladott életkora és a társbetegségek magas száma.

\section{Fizikai tréning idösekben}

A komplex kardiológiai rehabilitációs programok egyik leglényegesebb komponense a fizikai tréning. Időseknél különösképpen figyelnünk kell arra, hogy kiderüljenek a mozgásprogramot esetleg kontraindikáló tényezők. Azonban a tréningprogramot általában nem szükséges az életkor miatt alapjaiban módosítani.

Tekintetbe kell vennünk a szív- és érrendszer életkorral járó változásait, a csökkent maximális oxigénfelvételt és a perifériás oxigén-extrakciót, valamint az alacsonyabb elérhető maximális szívfrekvenciát (7). Figyelembe kell vennünk a fizikai inaktivitással és a szív-ér rendszeri alapbetegséggel kapcsolatos megromlott paramétereket, a társbetegségek közül pedig különösen azokat, amelyek rontják a mozgási képességeket.

Hangsúlyt kell fektetnünk a bemelegítésre, amelynek tartalmaznia kell hajlékonyságot fokozó és az ízületek teljes mozgásterjedelmére kiterjedő gyakorlatokat is. A bemelegítés felkészíti betegeink mozgási, keringési és légzési rendszerét a terhelésre.

A levezetés ugyanilyen fontos. Időt kell hagynunk a termelődött hő elvezetődésére, a terhelés által kiváltott vazodilatáció megszűnésére, így elkerülhető a vérnyomásesés. Az idős betegek hipotenzióra különösen érzékenyek, mivel a baroreceptor-érzékenységük csökkent. Idősekben a szívfrekvencia lassabban normalizálódik, ezért hosszabb szüneteket kell beiktatnunk az alacsony- és magas intenzitású gyakorlatok közé. Tekintetbe kell venni azt is, hogy az életkorral romlik a bőr vérellátása, csökken az izzadás és a hőreguláció hatékonysága: meleg vagy párás környezetben az idős betegek edzésintenzitását csökkenteni kell!

\section{Edzésterv idősek számára}

$A z$ aerob tréning célszerüen alacsony intenzitással, 2-3 MET-terheléssel kezdődjön, ez fokozatosan növelhető. Az elvégzett edzésmunka akkor megfelelő, ha az edzést követően a betegek csak enyhe fáradtságról számolnak be. Azok az idős betegek, akik alacsony terhelés mellett tünetmentesek és a magasabb intenzitásnak nincs kontraindikációja, fokozatosan egyre jobban terhelhetők. Az edzések intenzitása azonban közepesnél ne legyen magasabb.

A futás, ugrás és más fokozott ízületi terheléssel járó aerob aktivitás még a korábban fizikailag aktív idős betegek számára is kerülendő (8). Az idős nők a férfiaknál fokozottabban érzékenyek a vázizom-rendszeri sérülésekre.
Az idősek ideális edzésprogramja dinamikus, élvezetes, könnyen hozzáférhető és biztonságos. Tudnivaló, hogy a rövid és rendszeres séta kiválóan alkalmazható, mindenhol hozzáférhető, intenzitása pedig könnyen növelhető. További előnye, hogy nem kell hozzá speciális eszköz vagy külön helyiség, nincs szükség különösebb képességekre vagy megelőző edzésre sem. Sétáláskor kedvező körülmény, hogy közben a betegek kapcsolatot tarthatnak betegtársaikkal. Fiatalabb betegek edzésére a sétáltatás általában nem alkalmas, kivéve azoknál, akik extrém inaktív életet folytatnak.

Az edzésprogramnak tartalmaznia kell a karokat erősítő gyakorlatokat is. Az izmok funkcióját javító és az izomtömeget növelő gyakorlatok hozzájárulnak az idős betegek sikeres rehabilitációjához (8-10). Az American College of Sports Medicine ajánlása kitér az idősekben alkalmazandó edzésmódszerekre (11). Az ajánlás szerint 30 perces közepes intenzitású aerob fizikai aktivitást heti 5 napon kellene alkalmazni, vagy alternatívaként heti kétszer húsz percen keresztül intenzíven tréningezni.

A súlyzós rezisztencia-edzések során az összes föbb izomcsoportot meg kell mozgatni, az izomerősítő gyakorlatok ismétlési száma 10-15 között legyen. Heti 2 alkalommal kell végezni 10 perces hajlékonyságot fokozó gyakorlatokat. Az elesésekkel kapcsolatos sérülések megelőzése végett, idősekben egyensúlyjavító gyakorlatokat is kell végezni. A betegeket megtanítjuk arra, hogy a pulzusszámmal vagy a terhelés megélt szintjével mérni tudják az edzésük intenzitását. Jól alkalmazható a beszédteszt (talk test) is, miszerint a betegek csak olyan intenzíven edzenek, hogy még kényelmesen tudjanak közben beszélgetni társaikkal (12).

Sok idős betegnél a vizsgáló eljárásokkal kimutatható a néma iszkémia (terheléses EKG, stressz echo, szívizom-szcintigráfia stb.). Ilyenkor a betegeknek nincs mellkasi panaszuk, az esetleges légszomjat angina ekvivalensnek tekinthetjük. Az edzéseket a néma iszkémia jelentkezésekor mért szívfrekvencia 60-75\%-a fölé nem szabad emelnünk. Bizonyított, hogy már ez a terhelési szint is javítja az állóképességet, lényegesen komfortosabb a betegek számára és kevesebb a vázizom-rendszeri komplikáció is, mint a korábban ajánlott 70-85\%-os pulzustartománykor (8). Emellett, nem elhanyagolható szempont, hogy alacsonyabb intenzitás mellett a felügyelet nélküli tréningek biztonságosabbak és a hosszú távú adherencia is jobb.

\section{A fizikai tréning eredményei időssekben}

A rendszeres fizikai tréninggel megelőzhető a korral járó endothel-diszfunkció, csökken az oxidatív stressz és csökken az NO-lebomlás (13). Számos hemosztatikus faktor és a CRP szintje is alacsonyabb lesz, javul a plazma és a vér viszkozitása is (14). Kedvezően 
alakul az életkorral egyébként romló centrális artériás compliance (15). Javul az iszkémiás prekondicionálódás, a maximális oxigénfelvevő-képesség, a fizikai kondíció, a terhelhetőség és az állóképesség (16-20). Mindez hozzájárul ahhoz, hogy jobb lesz a betegek fizikuma és pszichikuma, csökken függőségük és ritkábban szorulnak egészségügyi ellátásra (21). A javuló hajlékonyság, ízületi mozgásképesség, egyensúly, stabilitás, izomerő, izomtónus és neuromuszkuláris koordináció hozzájárul ahhoz, hogy az idősek kevésbé lesznek hajlamosak elesésre és jobban részt tudnak venni a mindennapi tevékenységekben. Az edzések által csökken a csontok demineralizációja és az osteoporosis, ami különösen fontos szempont az idősebb nők számára (22).

A rehabilitációs programok részeként alkalmazott rendszeres fizikai edzések segítenek a testsúlykontrollban, hozzájárulnak az étrendi megszorítások sikeres betartásához, ami különösen fontos a dohányzással való szimultán megküzdéskor. Kimutatott, hogy az edzésprogramok kedvező hatással vannak a magas vérnyomásra és az inzulinrezisztenciára is.

A fizikai tréning javíthat az önbecsülésen és az önképen, kialakulhat a szubjektív jólét érzése, csökkenhet az aggódás és depresszió, valamint javul a motiváció (23). A kardiológiai rehabilitáció során javulhatnak a kognitív funkciók is (24).

\section{A kardiológiai rehabilitáció hatása a klinikai végpontokra idősekben}

A kardiológiai rehabilitáció idősekben is számos klinikai végpontban idéz elő javulást. A rendszeres testmozgás hatására a koszorúér-események kockázata minden korcsoportban csökken, a potenciális nyereség a magasabb rizikójú idősekben még kifejezettebb (25).

600000 Medicare beteg adatai szerint a rehabilitációs programokban résztvevők halálozása 21-34\%-kal csökkent (26). A túlélés, a hospitalizáció ideje és a fizikális funkciók azonos mértékben javultak a 65 évnél fiatalabbakban, a 65-74 évesekben és a 75 éven felüliekben is (27). Idősekre is kiterjedő, véletlen besorolásos klinikai vizsgálatok metaanalízise alapján a kardiális és összhalálozás javulása mellett számos rizikófaktor is kedvezően alakult (28). Egy 36000 beteget érintő kohorsz tanulmány alapján a rehabilitációs programok résztvevőinek túlélése 35\%-kal volt jobb, és ez egyformán kimutatható volt a 70 évnél fiatalabbak és idősebbek között (29).

Igazolódott, hogy a kardiológiai rehabilitáció szignifikánsan segíti az idősek napi aktivitását, jobban el tudják végezni a háztartási feladatokat, javul képességük az önálló életvitelre (30).

A funkcionális kapacitás, a szívfrekvencia-variabilitás, az életminőség és a munkavégző-képesség is javul $(20,21,31)$.

\section{Pszichoterápia}

Az egészségtudat elvesztése, a betegség állapota a lelki egyensúly átmeneti vagy tartós megváltozását okozhatja. Jól ismert, hogy infarktust követően gyakori a depresszió és a szorongás, amelyek már önmagukban is rontják a beteg kilátásait. A poszttraumás stresszzavart (post traumatic stress disorder, PTSD) korábban legtöbbször háborús veteránoknál és személy elleni támadások áldozatai esetén azonosították, de később kiterjesztették a diagnosztizált, életveszélylyel járó betegségekre (pl. szívinfarktus, szívmútét) is. A PTSD szívinfarktus után $6-22 \%$ gyakorisággal fordul elő, rendkívül romboló hatású lehet. Az érintett személynél gyakori az érzelmi kiüresedés, az alvászavarok, a depresszió, a szorongás, az ingerlékenység, a büntudatérzés vagy a dühkitörések. Emlékbetörések, rémálmok és rémisztő gondolatok formájában sok PTSD-ben szenvedő ember újra meg újra átéli a traumatizáló eseményt. Infarktus utáni PTSD esetén romlik az életminőség, csökken a gyógyszer-adherencia és nő a rehospitalizációk száma.

Mivel lelki stabilitásuk megingásáról a betegeknek csak egy része hajlandó beszámolni, a psziché explorálása a kardiológiai rehabilitáció egyik fontos feladata. A beteg pszichológiai állapotát az orvosi interjú során a beteg megfigyelésével, szürőtesztekkel és a klinikai (szak) pszichológus által végzett pszichodiagnosztikai tesztek segítségével mérhetjük fel. Nem elegendő csak depresszió irányába szűrni, mivel így a PTSD-esetek jelentős része nem kerül felismerésre.

A depresszió és a PTSD mellett számos egyéb pszichológiai állapotról igazolták, hogy a kardiovaszkuláris megbetegedések önálló rizikótényezője. Így a hostilitás, az „A" és „D” személyiségjegyek, a krónikus stressz, a szociális izoláció és az alacsony szocio-ökonómiai státusz miatti tennivalók a rehabilitációs teamben dolgozó orvos, pszichológus, mentálhigiénikus és szociális munkatárs összehangolt intervencióját igénylik.

A pszichoterápia lehet egyéni és csoportos. A témacentrikus csoportbeszélgetések és az autogén tréning mellett különösen fontos a házastárs és családterápia, miáltal a hozzátartozók is részt vállalnak a gyógyulásban, segítik a beteg stabilizálódását, előmozdítják az önállóság minél további fennmaradását. Ez különösen fontos, ha figyelembe vesszük, hogy milyen magas az egyedül élő idősek száma, hiszen 2013-ban az EU-ban az egyszemélyes háztartások 29\%-át 65 évnél idősebbek tették ki (32).

\section{Esendőségszindróma (frailty syndrome)}

Az esendőségszindrómára (ES) már az 1950-es évekből vannak irodalmi utalások, definíció tekintetében a legnagyobb előrelépés 2001-ben volt (33). Eszerint az esendő fenotípusnak az etiológiától függetlenül 5 veze- 
4. TÁBLÁZAT. A FRAIL skála Morley és munkatársai nyomán (34)

\begin{tabular}{|c|c|}
\hline Fatigue & $\begin{array}{l}\text { Fáradtság és gyengeség } \\
\text { érzése az elmúlt } 1 \text { hónapban }\end{array}$ \\
\hline Rezisztencia (erőnlét) & Nem képes egy fordulónyit lépcsőzni \\
\hline Aerob izommunka & Nem képes 100 m-t sétálni \\
\hline Betegség & $\begin{array}{l}\text { ismert betegségek száma >5 (de- } \\
\text { mentia, szívbetegség, depresszió, } \\
\text { arthritis, asztma, bronchitis, emphy- } \\
\text { sema, diabétesz, magas vérnyomás, } \\
\text { osteoporosis, stroke }\end{array}$ \\
\hline Súlycsökkenés & $\begin{array}{l}\text { Testsúlycsökkenés }>5 \% \text { az elmúlt hat } \\
\text { hónapban }\end{array}$ \\
\hline
\end{tabular}

Minden pozitív válasz 1 pontot ér. $0=$ egészséges=robust; $1-2=$ esendőség-prodroma=pre-frailty; $\geq 3$ = esendőségszindróma=frailty

tő tünete van: testsúlycsökkenés, izomgyengeség, kimerültség, meglassultság, csökkent aktivitás.

Egyszerú és a klinikai gyakorlatban ígéretesnek tủnik a FRAIL-skála alkalmazása, habár nem veszi figyelembe a mentális állapotot, a kognitív funkcióromlást és a szociális vulnerabilitást (4. táblázat) (34).

Az ES gyakorisága az életkorral nő, 80 év felett mintegy $20 \%$ és nőknél kb. kétszer gyakoribb (35). Az izomgyengeség a leggyakoribb első tünet, az esetek $75 \%$-ában az ezzel kapcsolatos meglassultság és aktivitáscsökkenés is megelőzi a kimerültséget és a testsúlyvesztést (36). A prevencióban kihasználható, hogy az ökölbe szorítási erő korrelál a rokkantsággal, a mortalitással és a kognitív leépüléssel, így az izomgyengeség lehet a legszenzitívebb jel.

Az ES-ben szenvedők vulnerabilitása fokozott, kimerült a szervezet homeosztatikus rezerv kapacitása, így egy kisebb stressz (infekció, haláleset a családban stb.) a vártnál nagyobb és gyors egészségromláshoz vezethet. A felépülés is lassabb, így nagyobb az esély a további maradandó károsodások elszenvedésére. Fontos tudnivaló, hogy az esendőség tulajdonképpen gyorsan romló egészségi állapotot jelent, így a testi-szellemi leépülés előszobájának tekinthető. Az orvos-beteg találkozások során, különösen 70 év felett, mindig gondolnunk kell az ES lehetőségére is. Korai stádiumban felismerve az ES reverzibilis lehet, megelőzhető a további egészségkárosodás és az önállóság elvesztése. Gyakorlott vizsgáló a klinikum alapján felismerheti, de egyszerű szűrőeszközként a FRAIL-skála is ajánlható. Az egyéni gondozási terv felállításakor tartsuk szem előtt, hogy a kórkép multifaktoriális, a progressziót biológiai, lelki és társadalmi-gazdasági tényezők befolyásolják. Evidenciák vannak a testmozgás, a kalória-, fehérje- és D-vitamin-bevitel hatékonyságára. Fontos a polifarmácia redukciója, a társszakmák és hozzátartozók bevonása. Reális célkitűzés a funkcionalitás megőrzése, az életminőség javítása, és az ES okozta fokozott egészségügyi rizikó mérséklése (37).

$A z$ esendő szívbetegek esetében törekednünk kell arra, hogy azonosítsuk az esetleges visszafordítható tényezőket és a nem feltétlenül orvosi kompetenciához kötött feladatok megoldásában pedig mindig gondoljuk a team egyéb, nem orvos tagjainak bevonására! Az idős szívbetegekben gyakori heveny delírium sokszor már a kórházi felvételt is bonyolítja, csökkent önellátó-képességgel jár, emeli a hospitalizáció idejét és a halálozást. Az esendő betegek rehabilitációjában javasolt a multidiszciplináris teamet demencia-specialistákkal kiegészíteni, szükséges a család és a gondozók aktív bevonása is, amely hosszú távon javíthatja a beteg adherenciáját.

\section{Következtetések}

- A rendelkezésünkre álló adatok szerint idősekben a kardiológiai rehabilitáció által elérhető rizikócsökkenés hasonló a fiatalabbakéhoz.

- Idősebbek számára alacsonyabb intenzitású edzésprogram javasolt, amelynek hajlékonyságot fokozó gyakorlatokat is tartalmaznia kell.

- A kardiológiai rehabilitáció által minden korosztályban csökkenthető a mortalitás és a morbiditás, de idősekben javul a fizikális kondíció és teljesítmény és kedvezően változik a hajlékonyság, az ízületi mobilitás, az egyensúly, a stabilitás, az izomerő és az izomtónus is. - Koszorúér-esemény vagy szívelégtelenség miatt hospitalizált 65 évnél idősebbek kockázata fokozott a tartós állapotromlásra. A szívinfarktust vagy revaszkularizációs procedúrákat követő prolongált hospitalizáció prediszponáló tényezője a dekondicionálódásnak.

- Figyelni kell arra, hogy 65 évesnél idősebbekben észleljük az esendőség szindrómát, mert időben felismerve kedvezően befolyásolható.

- A kardiológiai rehabilitációnak fel kell készülnie az esendő és végstádiumú szívbetegekkel való foglalkozásra is.

\section{Irodalom}

1. forrás: http://ec.europa.eu/eurostat/statistics-explained/index. php/Population_structure_and_ageing

2. Herskind $\mathrm{AM}_{\bar{M}}$, McGue $\overline{\mathrm{M}}$, Holm NV, et al. The heritability of human longevity: a population-based study of 2872 Danish twin pairs born 1870-1900. Hum Genet 1996; 97: 319. https://doi.org/10.1007/ BF02185763

3. Ljungquist B, Berg S, Lanke J, McClearn GE, Pedersen NL. The effect of genetic factors for longevity: a comparison of identical and fraternal twins in the Swedish Twin Registry. J Gerontol A Biol Sci Med Sci 1998; 53:441. https://doi.org/10.1093/gerona/53A.6.M441

4. Curtsinger JW, Fukui HH, Khazaeli AA, et al. Review Genetic variation and aging. Annu Rev Genet 1995; 553: 75. https://doi. org/10.1146/annurev.ge.29.120195.003005

E. Finch CE, Tanzi RE. Review Genetics of aging. Science 1997; 278: 407. https://doi.org/10.1126/science.278.5337.407

5. Vaupel JW. Biodemography of human ageing. Nature 2010; 424: 536.

6. Fleg JL, Lakatta EG. Role of muscle loss in the age-associated reduction in VO2 max. J Appl Physiol 1988; 65: 1147.

7. Pollock ML, Carroll JF, Graves JE, et al. Injuries and adherence to walk/jog and resistance training programs in the elderly. Med Sci 
Sports Exerc 1991; 23: 1194.

8. Bruce RA, Larson EB, Stratton J, et al. Physical fitness, functional aerobic capacity, aging, and response to physical training or bypass surgery in coronary patients. J Cardiopulmonary Rehabil 1989; 9: 24 9. Fiatarone MA, Marks EC, Ryan ND, et al. High-intensity strength training in nonagenarians. Effects on skeletal muscle. JAMA 1990; 263: 3029. https://doi.org/10.1001/jama.1990.03440220053029

10. Nelson ME, Rejeski WJ, Blair SN, et al. Physical activity and public health in older adults: recommendation from the American College of Sports Medicine and the American Heart Association. Circulation 2007; 116: 1094. https://doi.org/10.1161/CIRCULATIONAHA.107.185650

11. Borg GA. Psychophysical bases of perceived exertion. Med Sci Sports Exerc 1982; 14: 377.

12. Taddei S, Galetta F, Virdis A, et al. Physical activity prevents age-related impairment in nitric ohttps://doi.org/10.1161/01. CIR.101.25.2896

13. Wannamethee SG, Lowe GD, Whincup PH, et al. Physical activity and hemostatic and inflammatory variables in elderly men. Circulation 2002; 105: 1785. https://doi.org/10.1161/01. CIR.0000016346.14762.71

14. Tanaka H, Dinenno FA, Monahan KD, et al. Aging, habitual exercise, and dynamic arterial compliance. Circulation 2000; 102: 1270. https://doi.org/10.1161/01.CIR.102.11.1270

15. McGuire DK, Levine BD, Williamson JW, et al. A 30-year follow-up of the Dallas Bedrest and Training Study: I. Effect of age on the cardiovascular response to exercise. Circulation 2001; 104: 1350. https://doi.org/10.1161/hc3701.096099

16. Abete P, Ferrara N, Cacciatore F, et al. High level of physical activity preserves the cardioprotective effect of preinfarction angiha in elderly patients. J Am Coll Cardiol 2001; 38: 1357. https://doi org/10.1016/S0735-1097(01)01560-1

17. Beere PA, Russell SD, Morey MC, et al. Aerobic exercise training can reverse age-related peripheral circulatory changes in healthy older men. Circulation 1999; 100: 1085. https://doi.org/10.1161/01. CIR.100.10.1085

18. Marchionni N, Fattirolli F, Fumagalli S, et al. Improved exercise tolerance and quality of life with cardiac rehabilitation of older patients after myocardial infarction: results of a randomized, controlled trial. Circulation 2003; 107: 2201. https://doi.org/10.1161/01. CIR.0000066322.21016.4A

19. Ståhle A, Mattsson E, Rydén L, et al. Improved physical fitness and quality of life following training of elderly patients after acute coronary events. A 1 year follow-up randomized controlled study. Eur Heart J 1999; 20:1475. https://doi.org/10.1053/euhj.1999.1581

20. Blumenthal JA, Emery CF, Madden DJ, et al. Cardiovascular and behavioral effects of aerobic exercise training in healthy older men and women. J Gerontol 1989; 44:M147. https://doi.org/10.1093/geronj/44.5.M147

21. Pocock NA, Eisman JA, Yeates MG, et al. Physical fitness is a major determinant of femoral neck and lumbar spine bone mineral density. J Clin Invest 1986; 78: 618. https://doi.org/10.1172/ JCl112618

22. Milani RV, Lavie CJ. Prevalence and effects of cardiac reha- bilitation on depression in the elderly with coronary heart disease. Am J Cardiol 1998; 81: 1233. https://doi.org/10.1016/S00028703(96)90304-X

23. Stanek KM, Gunstad J, Spitznagel MB, et al. Improvements in cognitive function following cardiac rehabilitation for older adults with cardiovascular disease. Int J Neurosci 2011; 121: 86. https://doi. org/10.3109/00207454.2010.531893

24. Wenger NK. Cardiovascular disease in the elderly. Curr Probl Cardiol 1992; 17: 609. https://doi.org/10.1016/S0735-1097(87)80456-4 25. Suaya JA, Stason WB, Ades PA, et al. Cardiac rehabilitation and survival in older coronary patients. J Am Coll Cardiol 2009; 54: 25. https://doi.org/10.1016/j.jacc.2009.01.078

26. Frengley JD, Sansone GR, Alba A, et al. Influence of age on rehabilitation outcomes and survival in post-acute inpatient cardiac rehabilitation. J Cardiopulm Rehabil Prev 2011; 31: 230. https://doi. org 10.1097/HCR.0b013e318207d314

27. Taylor RS, Brown A, Ebrahim S, et al. Exercise-based rehabilitation for patients with coronary heart disease: systematic review and meta-analysis of randomized controlled trials. Am J Med 2004; 116:682. https://doi.org/10.1016/j.amjmed.2004.01.009

28. de Vries H, Kemps HM, van Engen-Verheul MM, et al. Cardiac rehabilitation and survival in a large representative community cohort of Dutch patients. Eur Heart J 2015; 36: 1519. https://doi org/10.1093/eurheartj/ehv111

29. Johnston M, MacDonald K, Manns P, et al. Impact of cardiac rehabilitation on the ability of elderly cardiac patients to perform common household tasks. J Cardiopulm Rehabil Prev 2011; 31: 100. https://doi.org/10.1097/HCR.0b013e3181f1fd8c

30. Lai FC, Tu ST, Huang CH, Jeng C. A home-based exercise program improves heart rate variability and functional capacity among postmenopausal women with coronary artery disease. J Cardiovasc Nurs 2011; 26: 137. https://doi.org/10.1097/JCN.0b013e3181ed9424 31.forrás:http://ec.europa.eu/eurostat/statistics-explained/index. php/People_in_the_EU_\%E2\%80\%93_statistics_on_household_ and_family_structures

32. Fried LP, Tangen CM, Walston J, et al. Frailty in older adults: evidence for a phenotype. J Gerontol A Biol Sci Med Sci 2001; 56 : M146. https://doi.org/10.1093/gerona/56.3.M14

33. Morley JE, Vellas B, van Kan GA, et al. Frailty consensus: a call to action. J Am Med Dir Assoc 2013; 14:392. https://doi.org/10.1016/j. jamda.2013.03.022

34. Polidoro A, Dornbusch T, Vestri A et al. Frailty and disability in the elderly: a diagnostic dilemma. Arch Gerontol Geriatr 2011; 52 : 75. https://doi.org/10.1016/j.archger.2010.06.001

35. Gill TM, Gahbauer EA, Allore HG, et al. Transitions between frailty states among community-living older persons. Arch Intern Med 2006; 166: 418. https://doi.org/10.1001/archinte.166.4.418

36. Kálmán S, Pákáski M, Kálmán J. Esendőségszindróma: egy régi új ismerős. Orv Hetil 2014; 155:49. https://doi.org/10.1556/ OH.2014.30039

37. Jaarsma T, Beattie JM, Ryder M, et al. Palliative care in heart failure: a position statement from the palliative care workshop of the Heart Failure Association of the European Society of Cardiology. Eur J Heart Fail 2009; 11: 433. https://doi.org/10.109 3/eurjhf/hfp041 